Received: 2019.03.31 Accepted: 2019.06 .20 Published: 2019.08.19

Authors' Contribution: Study Design A Data Collection B Statistical Analysis C Data Interpretation D Manuscript Preparation E Literature Search F Funds Collection G

Corresponding Authors: Conflict of interest:

\title{
Sarcomatoid Chromophobe Renal Cell Carcinoma: A Case Report and Review of the Literature
}

DE 1 Lihui Bian*

BE 1 Jingling Duan*

F 1 Xiaoyu Wang

D 1 Yang Yang

AG 2 Xiaoling Zhang

AG 1 Shengjun Xiao
1 Department of Pathology, The Second Affiliated Hospital of Guilin Medical University, Guilin, Guangxi, P.R. China

2 Department of Physiology, Faculty of Basic Medical Sciences, Guilin Medical University, Guilin, Guangxi, P.R. China

* Lihui Bian and Jingling Duan contributed equally to this work

Shengjun Xiao, e-mail: xiaoshengjun@glmc.edu.cn, Xiaoling Zhang, e-mail: rose2006@glmc.edu.cn

None declared

\begin{abstract}
Patient: Female, 63
Final Diagnosis: Sarcomatoid chromophobe renal cell carcinoma

Symptoms: Painless gross hematuria

Medication: -

Clinical Procedure: -

Specialty: Renal Surgery

Objective: Rare disease

Background: Sarcomatoid renal cell carcinoma is not a distinct histologic entity transformed from different subtypes of renal cell carcinoma. The sarcomatoid transformation was accepted as the result of dedifferentiation of the primary tumor. Here we present a case of sarcomatoid chromophobe renal cell carcinoma and review the clinicopathological characteristics of sarcomatoid chromophobe renal cell carcinoma.

Case Report: A 63-year-old female complained of painless gross hematuria for 3 months. Routine urine test showed that urinary protein was ++ and white blood cells were +++; serum CA153 was moderately elevated at $71.08 \mathrm{U} / \mathrm{mL}$ (normal $<28 \mathrm{U} / \mathrm{mL}$ ). Ultrasonography and a computed tomography scan showed a mass in the lower pole of the right kidney, measuring $13.4 \times 15.4 \times 11.4 \mathrm{~cm}$. She underwent a right radical nephrectomy with lymph nodes dissection under general anesthetic. There was no evidence of recurrence and lymphadenopathy 12 months after surgery.

Conclusions: Sarcomatoid chromophobe renal cell carcinoma is an uncommon tumor characterized by a biphasic tumor with both classical epithelial components and sarcomatoid components. The prognosis of sarcomatoid chromophobe renal cell carcinoma is worse than classical chromophobe renal cell carcinoma. It is important to recognize that sarcomatoid change of chromophobe renal cell carcinoma has the potential to behave aggressively and to metastasize.
\end{abstract}

MeSH Keywords: Carcinoma, Renal Cell • Neoplasm Metastasis • Pathology, Clinical

Full-text PDF: $\quad$ https://www.amjcaserep.com/abstract/index/idArt/916651

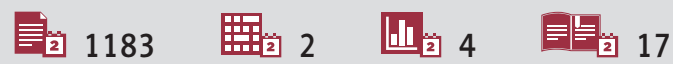




\section{Background}

Sarcomatoid changes are rarely seen in epithelial malignancy, which has been found in kidney, breast, esophagus, lung, kidney, and urinary bladder, carrying an ominous prognosis [1]. Malignant tumors with sarcomatoid changes have a 35\% and 27\%, 5-year disease specific and progression-free survival, respectively [2]. Sarcomatoid differentiation has been reported to occur in $>5 \%$ of all renal cell carcinomas (RCCs) [3]. Chromophobe renal cell carcinoma (ChRCC), which originates from distal convoluted tubules and cortical collecting ducts, is a distinct subtype of renal cell carcinoma [3], which accounts for $4 \%$ to $6 \%$ of renal cell carcinoma subtypes [4]. Most ChRCC have good prognosis, but sarcomatoid change is a poor prognostic factor. Sarcomatoid transformation from epithelioid elements were believed to be a process of malignant progression. Here we present a case of sarcomatoid ChRCC with undifferentiated pleomorphic sarcoma-like elements and review the clinicopathological characteristics of sarcomatoid ChRCC.

\section{Case Report}

\section{Clinical history}

On April 14, 2016, a 63-year-old female complained of painless gross hematuria for 3 months without family history. Routine urine test showed that urinary protein was ++ and white blood cells were +++ ; serum CA153 was moderately elevated at $71.08 \mathrm{U} / \mathrm{ml}$ (normal $<28 \mathrm{U} / \mathrm{mL}$ ). Ultrasonography and a computed tomography (CT) scan showed a mass in lower pole of the right kidney, measuring $13.4 \times 15.4 \times 11.4 \mathrm{~cm}$. CT scan is shown in Figure 1. Tissue samples are shown in Figure 2. The patient underwent a right radical nephrectomy with lymph nodes dissection under general anesthetic. There was no evidence of recurrence and lymphadenopathy at 12 months after surgery.

\section{Material and methods}

The resected specimens were fixed in $10 \%$ neutral buffered formalin, embedded in paraffin, sliced in 4- $\mu \mathrm{m}$ thick sections and stained with routine hematoxylin and eosin staining and viewed under light microscopy. Immunohistochemical staining was done using the EnVision 2-step method. The primary anticytokeratin, vimentin, CD68, CD117, Ki-67, EMA, E-cadherin, and CK7 were purchased from Fuzhou Maixin Company. Antigen repair and immunohistochemical staining steps were performed in strict accordance with kit instructions; the staining process was set using positive and negative control DAB color. According to the different parts of the antibody coloring, tumor cell cytoplasm, membrane, or nucleus was brown to determine positive.

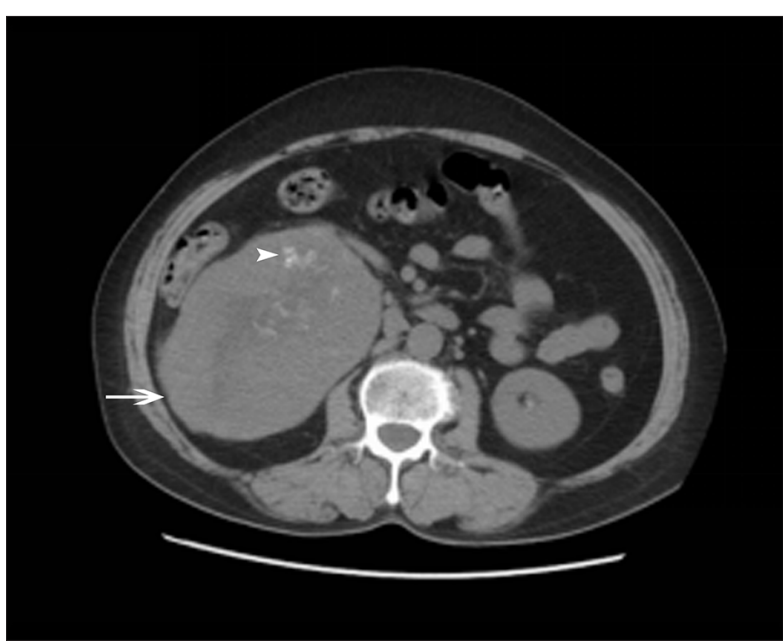

Figure 1. Computed tomography (CT) scan of lesion. Arrow: Soft tissue mass is seen below the right kidney, which of the size was $13.4 \times 15.4 \times 11.4 \mathrm{~cm}$; Arrowhead: CT scan showed the case had a calcified area inside in soft tissue mass.

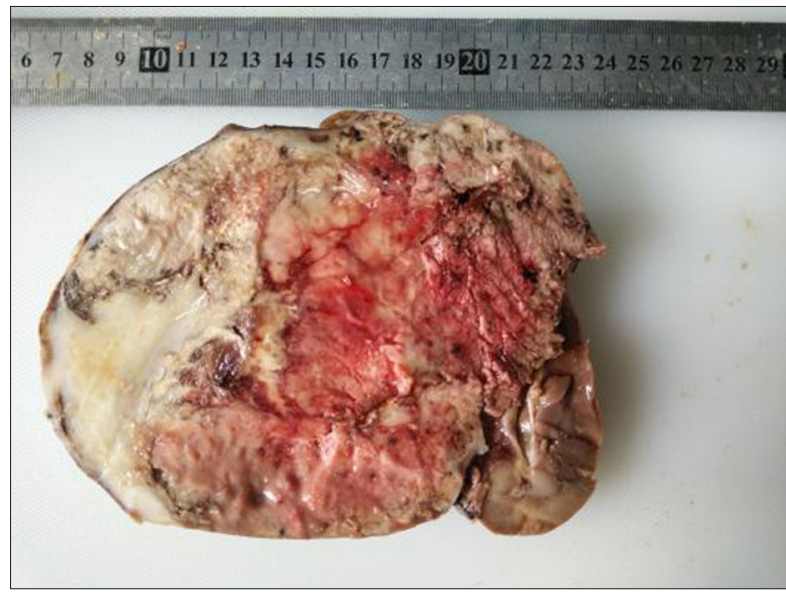

Figure 2. Gross morphology. Cut section of the right kidney showed a well-demarcated large tumor with a variegated appearance.

\section{Gross}

The surgically resected kidney was bisected to reveal a well encapsulated, colorful mass occupying the lower pole. The size of the mass is $14 \times 10 \times 7 \mathrm{~cm}$. The cut surface was predominantly solid and colorful. The majority area of the tumor was tangray, along with areas of yellowish necrosis, hemorrhage, and a tan-white area in the lower portion (Figure 1).

\section{Histology and immunohistochemistry}

Microscopically, sections showed a biphasic malignant neoplasm with epithelial and sarcomatoid features. The tan-gray areas showed a typical ChRCC morphology, which consisted of large 


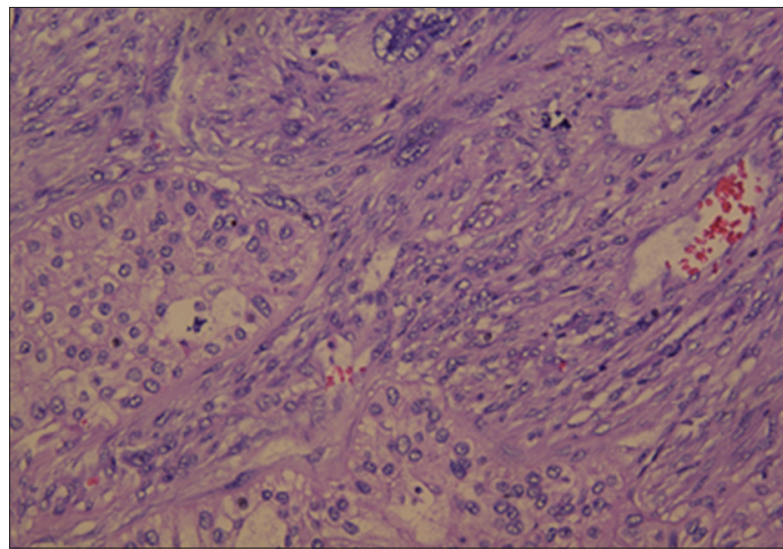

Figure 3. Hematoxylin and eosin stained section. The chromophobe renal cell carcinoma cells had eosinophilic to pale cytoplasm with accentuated cell borders. Nuclei are centrally located with wrinkled nuclear membranes. The spindle sarcomatoid cells were arranged in ill-defined fascicles or storiform with occasionally tumor giant cells. Original magnification $400 x$.
Table 1. The immunohistochemical features of sarcomatoid chromophobe renal cell carcinoma.

\begin{tabular}{|cccc}
\hline Antibody & Clone & ChRCC & $\begin{array}{c}\text { Sarcomatoid } \\
\text { cells }\end{array}$ \\
\hline Cytokeratin & AE1/AE3 & +++ & + \\
\hline EMA & E-29 & +++ & + \\
\hline Vimentin & V9 & - & +++ \\
\hline CD117 & YR145 & +++ & - \\
\hline CD68 & KP1 & +++ & - \\
\hline CK7 & OV-TL $12 / 30$ & - & + \\
\hline E-cadherin & MX020 & ++ & - \\
\hline
\end{tabular}

ChRCC - chromophobe renal cell carcinoma.
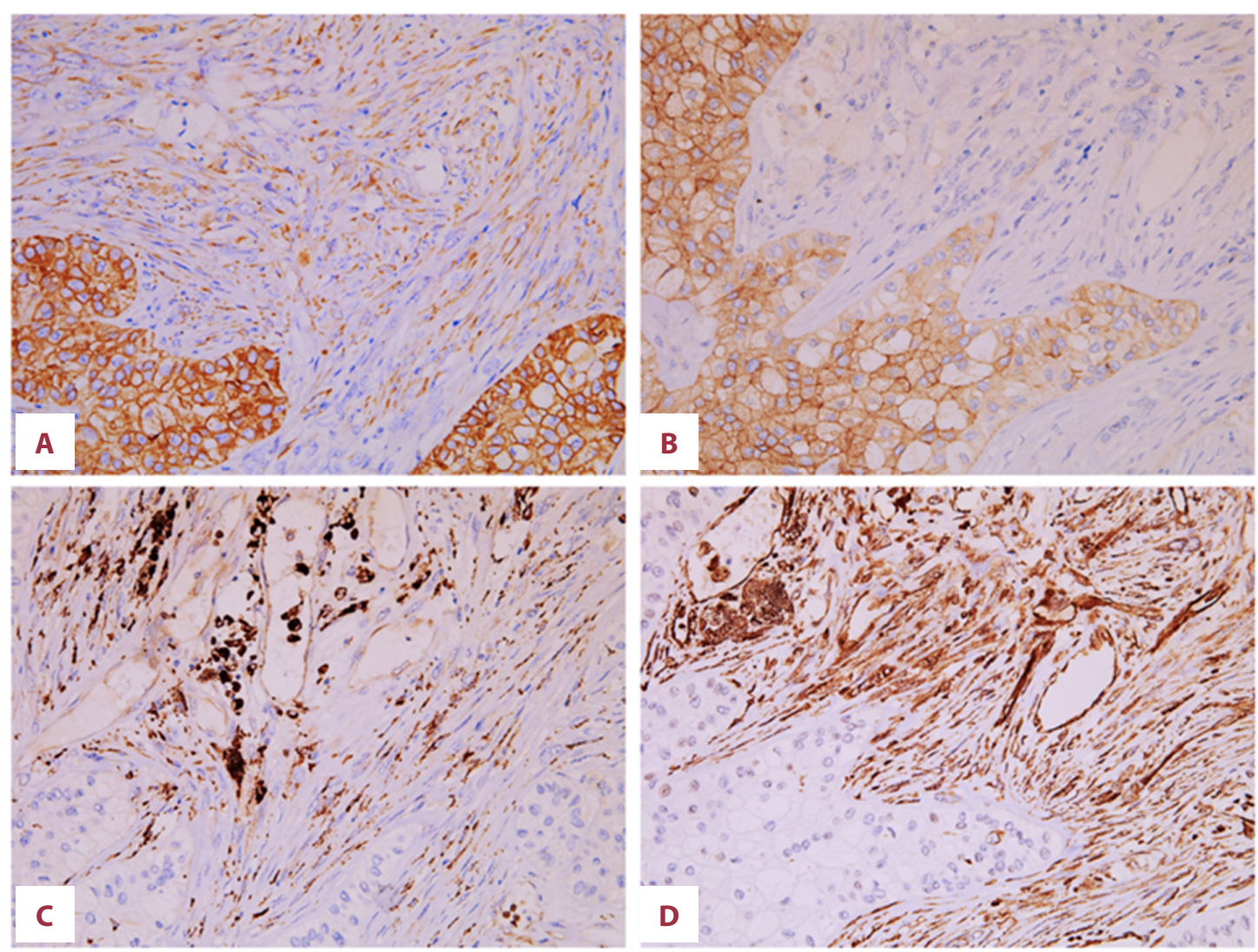

Figure 4. Immunohistochemical features of the tumor. (A) Chromophobe renal cell carcinoma (ChRCC) components were strongly immunostained for pan CK, while sarcomatoid components were weakly immunostained. Original magnification 400x. (B) The ChRCC cells were strongly immnostained in the membrane, for CD117. Original magnification 400x. (C) The spindle cells were strongly positive for CD68 with a paranuclear dot-like pattern. Original magnification 400x. (D) The sarcomatoid area was strongly positive for vimentin. Original magnification $400 x$. 
Table 2. Clinical and morphologic features of sarcomatoid chromophobe renal cell carcinoma.

\begin{tabular}{|c|c|c|c|c|c|c|c|}
\hline Author & $\begin{array}{l}\text { Diagnosis } \\
\text { time }\end{array}$ & $\begin{array}{c}\text { Age } \\
\text { Year/sex }\end{array}$ & $\begin{array}{l}\text { Greatest } \\
\text { dimension }\end{array}$ & $\begin{array}{l}\text { TNM } \\
\text { tage }\end{array}$ & Metastasis & Clinical behavior & $\begin{array}{l}\text { Sarcomatoid } \\
\text { components }\end{array}$ \\
\hline $\begin{array}{l}\text { Itoh } \\
\text { et al. [10] }\end{array}$ & Unknown & $74 / M$ & 19.0 & T4NxM1 & $\begin{array}{l}\text { Intraabdominal, } \\
\text { liver, colon, and } \\
\text { pulmonary }\end{array}$ & $\begin{array}{l}\text { Died after } 1 \\
\text { month }\end{array}$ & $\begin{array}{l}2 / 3 \\
\text { (osteosarcoma-like } \\
\text { component) }\end{array}$ \\
\hline $\begin{array}{l}\text { Viswanathan } \\
\text { et al. [12] }\end{array}$ & Unknown & $45 / F$ & 20.0 & T2NxM1 & $\begin{array}{l}\text { Liver, right kidney } \\
\text { Lung, } 12 \text { to L1 } \\
\text { vertebrae }\end{array}$ & Died in 1 month & NA (spindle cells) \\
\hline $\begin{array}{l}\text { Gong } \\
\text { et al. [11] }\end{array}$ & Unknown & $72 / M$ & 7.0 & T1bNxM1 & $\begin{array}{l}\text { lungs, peritoneum, } \\
\text { the distal small } \\
\text { intestine, psoas } \\
\text { muscle }\end{array}$ & NA & NA (spindle cells) \\
\hline $\begin{array}{l}\text { Tanaka } \\
\text { et al. [13] }\end{array}$ & Unknown & $77 / M$ & 2.5 & T1aNOMO & None & $\begin{array}{l}\text { Alive after } 12 \\
\text { months }\end{array}$ & $\begin{array}{l}\text { NA (osteosarcoma } \\
\text { component) }\end{array}$ \\
\hline $\begin{array}{l}\text { Quiroga-Garza } \\
\text { et al. [5] }\end{array}$ & 2006 & $63 / F$ & 6.0 & T1bN1M1 & None & $\begin{array}{l}\text { Alive after } 10 \\
\text { months }\end{array}$ & $\begin{array}{l}70 \% \\
\text { (osteosarcoma and } \\
\text { chondrosarcoma } \\
\text { components) }\end{array}$ \\
\hline $\begin{array}{l}\text { Hes } \\
\text { et al. [14] }\end{array}$ & Unknown & $74 / M$ & 12.0 & T2bNXMX & None & $\begin{array}{l}\text { Died in } 3.5 \\
\text { months }\end{array}$ & $\begin{array}{l}\text { NA (osteosarcoma, } \\
\text { chondrosarcoma, } \\
\text { and } \\
\text { rhabdomyoblastic } \\
\text { components) }\end{array}$ \\
\hline $\begin{array}{l}\text { Daga } \\
\text { et al. [15] }\end{array}$ & 2012 & $40 / F$ & 16.0 & T2bNOM1 & None & $\begin{array}{l}\text { Alive after } 12 \\
\text { months }\end{array}$ & $\begin{array}{l}40-50 \% \\
\text { (pleomorphic } \\
\text { spindle cells and } \\
\text { fibrosarcoma-like } \\
\text { components) }\end{array}$ \\
\hline Present case & 2016 & $63 / F$ & 14.0 & T2bNOMO & None & Alive until now & $\begin{array}{l}20 \% \\
\text { (undifferentiated } \\
\text { pleomorphic } \\
\text { sarcoma) }\end{array}$ \\
\hline
\end{tabular}

M - Male; F - female; NA - not available.

and polygonal cells with accentuated cell borders, abundant pale granular eosinophilic cytoplasm, a prominent perinuclear halo. Spindle sarcomatoid cells, which arranged in ill-defined fascicles storiform among the well differentiated epithelioid nests, were poorly differentiated with prominent nuclear pleomorphism and dispersed tumor giant cells (Figure 3).

The ChRCC cells were positive for epithelial membrane antigen EMA, pan-cytokeratin, CD117, CK7, CD10, and E-cadherin, but negative for vimentin. The sarcomatoid components were strongly stained for vimentin, and weakly stained for cytokeratin and EMA. CD68 staining showed a paranuclear dot-like pattern (Figure 4). Ki-67 index was approximately $30 \%$ in the sarcomatoid area, whereas it was $2 \%$ in the ChRCC areas (Table 1 ).

Using morphology and immunophenotype, the sarcomatoid components, which have pleomorphic cells with CD68 para-nuclear dot-like stained and disorder tissue structure, are easily diagnosed as undifferentiated sarcoma.

\section{Discussion}

ChRCC has been recognized as an uncommom subtype of RCC in humans for more than 30 years and was first described by Thoenes et al. in 1985 [5] it accounts for $5.9 \%$ of RCCs [2]. The 5-year and 10-year cancer-specific survival rates have been reported to be $78 \%$ to $100 \%$ and $80 \%$ to $90 \%$, respectively [2]. However, sarcomatoid differentiation of ChRCC is generally associated with a worse prognosis. In a study of 101 patients with sarcomatoid RCC (88 with available follow-up), de Peralta-Venturina et al. [6] reported a cancer-specific survival rate at 5 years of $22 \%$. Furthermore, the Akhtar et al. [7] study indicated that it might be the most common type with 
sarcomatoid transformation among all RCCs, and their study results showed that sarcomatoid differentiation was found in 6 of 11 cases (55\%) in chromophobe renal carcinoma. In addition, metastatic ChRCC has been found to have a high incidence of sarcomatoid features (50\%) [8]. But these studies still do not confirm a chromophobe connection in sarcomatoid renal cell carcinoma (SRCC), based on additional studies encompassing large numbers. The mechanism of sarcomatoid transformation is still largely unknown. But sarcomatoid carcinoma is widely accepted as being the result of malignant progression of a primary tumor. The sarcomatoid components are diverse, and can resemble fibrosarcoma, osteosarcoma, chondrosarcoma, malignant fibrous histiocytoma, or undifferentiated sarcoma [7-9]. The percentage of sarcomatoid component might be different from case to case. In some cases, it might be limited to a low percentage. In other cases, it might involve almost all areas [10]. Differential diagnosis includes the sarcoma aforementioned and collision tumor. The classic final diagnosis of sarcomatoid ChRCC depended on the presence of classic ChRCC and the sarcomatoid elements remained epithelial markers such as CK or EMA [11].

We searched the English literature in PubMed and found 7 cases of sarcomatoid ChRCC. The clinicopathological characters of these cases, including our present cases, are summarized in Table 2 [4,5,10-15]. The patients, 4 male and 4 female, were aged from 40 to 77 years (median age was 67.5 years). Tumor size were mostly large, varying from $2.5 \mathrm{~cm}$ to $20 \mathrm{~cm}$ in the greatest dimension. The histologic type of sarcomatoid components varied from case to case, most presented as osteosarcoma (4 out of 8 cases), and 3 were spindle cell sarcoma without histological subtype. The prognosis was poor, but there were still 2 cases alive after 12 months (Table 2)

\section{References:}

1. Lu BC, Wang C, Yu JH, Shen ZH, Yang JH. A huge adenosquamous carcinoma of the pancreas with sarcomatoid change: An unusual case report. World J Gastroenterol, 2014; 20(43): 16381-86

2. Amin MB, Amin MB, Tamboli P et al: Prognostic impact of histologic subtyping of adult renal epithelial neoplasms: An experience of 405 cases. Am J Surg Pathol, 2002; 26(3): 281-91

3. Przybycin CG, Cronin AM, Darvishian F et al: Chromophobe renal cell carcinoma: A clinicopathologic study of 203 tumors in 200 patients with primary resection at a single institution. Am J Surg Pathol, 2011; 35(7): 962-70

4. Al Ghamdi MH, Al Shabyli NA, Alayed A: Chromophobe renal cell carcinoma presenting as a cystic renal mass: Case report and review of the literature. Am J Case Rep, 2019; 20(1): 631-34

5. Quiroga-Garza G, Khurana H, Shen S et al: Sarcomatoid chromophobe renal cell carcinoma with heterologous sarcomatoid elements. A case report and review of the literature. Arch Pathol Lab Med, 2009; 133(11): 1857-60

6. de Peralta-Venturina $M$, Moch $\mathrm{H}$, Amin $M$ et al: Sarcomatoid differentiation in renal cell carcinoma: A study of 101 cases. Am J Surg Pathol, 2001; 25(3): 275-84

7. Akhtar M, Tulbah A, Kardar AH, Ali MA: Sarcomatoid renal cell carcinoma: The chromophobe connection. Am J Surg Pathol, 1997; 21(10): 1188-95
Clinically, it is well known that sarcomatoid differentiation of RCC is correlated with a poorer prognosis. Accumulated data indicate that the percentage of sarcomatoid elements (over $50 \%$ ), angio-invasion, and high TNM stage are correlated adversely with survival [6]. Metastatic SRCC remains a disease of poor prognosis and difficult to treat. Chemotherapy regimen and targeted therapies showed little activity in SRCC [16]. Renal cell cancer has previously been reported to show sensitivity to immunotherapy, indicating the possible advantage of immunomodulating therapies over standard treatment [17]. Prospective trials assessing new drugs, including immune checkpoint inhibitors, are currently ongoing study on improved SRCC survival [16].

In our literature review of sarcomatoid ChRCC cases, 5 cases were stage IV with metastasis, and 4 of these 5 cases died within several months. The high-grade clinical stage might be due to the high aggressive behavior of sarcomatoid elements.

\section{Conclusions}

In summary, sarcomatoid ChRCC is an uncommon tumor characterized by a biphasic tumor with both classical epithelial components and sarcomatoid components. The prognosis for sarcomatoid ChRCC is worse than for classical ChRCC. It is important to recognize that the sarcomatoid changes of ChRCC has the potential to behave aggressively and to metastasize.

\section{Conflicts of interest}

None.

8. Amin MB, Paner GP, Alvarado-Cabrero I et al: Chromophobe renal cell carcinoma: Histomorphologic characteristics and evaluation of conventional pathologic prognostic parameters in 145 cases. Am J Surg Pathol, 2008; 32(12): 1822-34

9. Li L, Teichberg S, Steckel J, Chen QH: Sarcomatoid renal cell carcinoma with divergent sarcomatoid growth patterns: A case report and review of the literature. Arch Pathol Lab Med, 2005; 129(8): 1057-60

10. Itoh T, Chikai K, Ota S et al: Chromophobe renal cell carcinoma with osteosarcoma-like differentiation. Am J Surg Pathol, 2002; 26(10): 1358-62

11. Gong $Y$, Sun $X$, Haines GK $3^{\text {rd }}$, Pins MR: Renal cell carcinoma, chromophobe type, with collecting duct carcinoma and sarcomatoid components. Arch Pathol Lab Med, 2003; 127(1): 38-40

12. Viswanathan S, Desai SB, Prabhu SR, Amin MB: Squamous differentiation in a sarcomatoid chromophobe renal cell carcinoma: An unusual case report with review of the literature. Arch Pathol Lab Med, 2008; 132(10): 1672-74

13. Tanaka Y, Koie T, Hatakeyama $S$ et al: Chromophobe renal cell carcinoma with concomitant sarcomatoid transformation and osseous metaplasia: A case report. BMC Urol, 2013; 13(1): 13-72

14. Hes $O$, Michal M, Kinkor Z et al: Sarcomatous chromophobe cell renal carcinoma: 2 case reports. Cesk Patol, 1999; 35(1): 15-19 
15. Daga D, Dana R, Kothari N: Chromophobe renal cell carcinoma with sarcomatoid changes: Case report and review of literature. Cent European Urol, 2014; 67(1): 31-34

16. Korenbaum C, Pierard L, Thiéry A et al: Treatments, outcomes, and validity of prognostic scores in patients with sarcomatoid renal cell carcinoma: A 20-year single-institution experience. Clin Genitourin Cancer, 2018; 16(3): e577-86
17. Ismailov Z, Rasa A, Bandere $\mathrm{K}$ et al: $\mathrm{A}$ case of stage iv chromophobe renal cell carcinoma treated with the oncolytic echo-7 virus, Rigvir ${ }^{\circledast}$. Am J Case Rep, 2019; 20: 48-52 